\title{
State Influence on the Development of Digital Economy of Rational Nature Use in Agricultural Sector of the Region's Economy
}

\author{
Nikolay V. ZHAKHOV ${ }^{1 *}$, Vladimir S. KRIVOSHLYKOV ${ }^{2}$, Natalya A. SLAVOVA ${ }^{3}$, \\ Irina A. GLEBOVA ${ }^{4}$, and Vladislav V. TURCHAKOV ${ }^{4}$ \\ ${ }^{1}$ South-West State University, Kursk, Russian Federation \\ ${ }^{2}$ Kursk State University, Kursk, Russian Federation \\ ${ }^{3}$ Branch of Russian State Humanitarian University in Domodedovo, Domodedovo, \\ Moscow Region, Russian Federation \\ ${ }^{4}$ Moscow State University of Technology and Management named after K.G. Razumovsky, \\ Moscow, Russian Federation \\ *Correspondence: zhakhov@mail.ru
}

\begin{abstract}
The article discusses the state influence on the development of digital economy of rational nature use in the agro-sector of the region's economy. The indicated sector of the region's economy demonstrates a mismatch between the tasks of the agroindustrial complex restructuring and the current market conditions oriented towards the widespread use of the digital economy elements, introduction of technological innovations and modernization of agricultural production. The modern way trends of the socio-economic system development dictate the need to use a development model that does not cause harm to nature or minimizes it. Realization of this statement can be ensured with a harmonious combination of environmental, innovative and economic components aimed at a balanced nature management. The authors assert that digital transformation of the agricultural sector should be considered as the basis of food security and the maximum production intensification. The key state program aimed at a direct impact implementation on environmental management in the agricultural sector of the region's economy through the digital economy has been analyzed. The conclusion is drawn on the application of this program at the regional level, as well as on a particular example of the experience of the state introducing modern management methods which have a synergistic effect for the real sector of the regional economy. The article presents some particular recommendations that should be paid attention while implementing the elements of the digital economy on the processes of environmental management in the agricultural sector of the region's economy.
\end{abstract}

Keywords: region's economy, nature management, innovations, state policy, regulation.

\section{Introduction}

Current trends dictate the need to use advanced digital technologies in the process of environmental management in the agricultural sector of the region's economy. Socioeconomic processes are accelerating the transition process to the digital economy; the 
correct application of modern innovative methods increases the effectiveness of managerial [1].

The dynamic regional development is a multi-faceted process influenced by economic, political, social, historical, environmental, technological, demographic and other factors. It should be mentioned that the influence of these factors has a multidirectional effect on the economical development as a whole, on agricultural sector and environmental management in particular. Along with the multidirectional factors, the structure of the regional economy and its functioning in general performing a direct impact on nature management in the agricultural sector of the region's economy are varied.

One of the most important conditions for the development of any territory is the rational, sustainable use of natural resources [2], ensuring a stable economic situation with the harmonious conservation and development of the environment, and restoration of natural resources [3].

Current trends of socio-economic systems' development dictate the need to use a development model that does not cause or minimizes harm to nature [4]. Realization of this idea can be ensured with a harmonious combination of environmental, innovative and economic components aimed at a balanced nature management.

The Russian economy, both at the federal and even more at the regional level, is aimed at dynamic development; it does not always adhere to environmental standards, mandatory methods, and environmental management rules.

\section{Methods}

Regardless of the structural transformation form, the impact of the digital economy in general on environmental management processes in the agricultural sector of the region's economy must comply with the following basic principles: parity of group, intragroup and regional interests; integration, consistency, purposefulness, efficiency, and optimality.

The theoretical basis of the formulations, devoted to the influence of the digital economy on the environmental management processes in the agricultural sector of the region's economy, are theories of regional growth and development. The research is guided by the idea of necessity to improve the management system of the regional socio-economic system and its subsystems in terms of introducing the digital economic foundations, the formation of new competencies of regional authorities. These competencies includes the widespread use of advanced management methods by means of information technologies, mobilization of internal reserves to ensure structural transformations in order to develop systematically the region's economy under the influence of the digital control introduction; development and implementation of strategic documents defining regional development guidelines in a line with federal interests; the use of effective management tools aimed at the processes of environmental management in the agricultural sector of the region's economy.

Using the methodological approaches presented above and analyzing the development of foreign and Russian researchers (N.D. Koryagin, A.I. Sukhorukov, B.B. Chagaeva (2018) [5], H.W. Chesbrough (2003) [6], Yu.P. Anisimov, I. V. Usacheva (2008) [7], Paul Trott (2012) [8], Kevin Blackwell, David Fazzina (2012) [9], B. Glassman, Ab Walton [10], M.V. Titova, A.Yu. Goncharov, N.V. Sirotkina (2015) [11], T.L. Bezrukova, R.A. Lesnykh, N.V. 
Sirotkina, A.N. Solomakhin (2006) [12], A.Yu. Goncharov, A.V. Polyakov, N.V. Sirotkina (2015) [13], N.V. Sirotkina, Yu.P. Anisimov (2008) [14], N.V. Sirotkina, E.A. Lanskikh (2011) [15], M.A. Gubanova, E.A. Bessonova, I.F. Anoshina (2017) [16], T.S. Kolmykova, E.A. Merzlyakova, V.V. Bredikhin, T.O. Tolstykh, O.P. Ovchinnikova (2018) [17], M. Serebryakova (2017) [18], E.F. Amirova, O.Y. Voronkova, K.A. Pyurveeva, M.A. Shatalov, T.A. Panteleeva, O.A. Sorokina (2018) [19], I.L. Vorotnikov, V.V. Neyfeld (2018) [20]), the special role of the synergetic paradigm, the concept of structural management of the regional economy, and the induction method that played a great role in substantiating the results of the study should be noted.

\section{Results and Discussions}

Agricultural sector of the region's economy demonstrates a mismatch between the structural restructuring of the agro-industrial complex and the modern market environment, focused on the innovative development path, the introduction of technological innovations and the modernization of agricultural production that fits rational environmental management features.

Since the modern period of the agro-industrial formation has started, it is observed a slow renewal of a key part of the main production assets, namely the machine and tractor fleet, equipment for livestock farms that meet modern standards, the technique of side work and processing of agricultural products. All the more, it can hardly be said about introducing innovative advanced technologies in the agro-industrial complex, which in turn contributes to the lag of the industry as a whole.

The challenges facing the world community are dictated by the following key global issues of environmental management problems as demographic, energy, water, food, depletion of land, forest resources.

Each of the mentioned global problems is not new; however, through the prism of introducing digital elements one can see the possibility of minimizing them and reducing the negative effect on nature management in the agricultural sector of the region's economy.

The digital transformation of the agricultural sector should be considered as a functionally oriented task of optimizing costs while increasing productivity of production, contributing to the solution of the problem of food security and maximum intensification of production.

As of today, the key state program is aimed at influencing directly the processes of environmental management in the agricultural sector of the region's economy by means of digital economy. This strategy is presented in the national program "Digital Economy of the Russian Federation" which provides for the transformation of a number of key priority sectors in economic and social spheres, including agriculture, with the introduction of digital technology and platform solutions [21]. At the initial stage of the development of this national program, expenditures from all sources amounted to $1.7 \%$ of GDP, according to the plan in 2019 they go up to 2.2\% of GDP, and by 2024 they will make $5.1 \%$ of GDP.

This program is not static and requires refinement for getting a more effective result of its implementation. Thus, having analyzed the national program "Digital Economy of the Russian Federation" in detail, we consider it is feasible to be supplied with relevant 
sections on some economic sectors (fields of activity). In particular, to pay more attention to the agricultural sector of the economy, for instance to add "Agriculture" as one of the strategic sectors for Russia (in terms of both ensuring food security and income generating from export revenue, which has already exceeded the arm export income 2 years ago), which possesses a very high potential for digitalization - from digital monitoring and control systems ("precision farming" and "accurate livestock farming") based on the Internet things and up to unmanned agricultural technology and unmanned aerial vehicles, as well as the introduction of exo-skeletons in the widespread usage for agricultural producers. Accordingly, funding should be provided for these areas [22]. It should be noted that "the Digital Economy Program" is cross-cutting systemic nature and creates the basis for the successful implementation of other national projects as management of crop germination, operating life of equipment based on continuous remote monitoring and new sensors.

At the regional level, the state program for agricultural development and regulation of agricultural products, raw materials and food markets for 2013-2020, approved by the RF Government Resolution No. 315 of 15/04/2014, determines the vector for the implementation of the targeted program approach in the regions of the Russian Federation.

Currently the development of agriculture at the regional level on the example of the Kursk Region is carried out with the realization of the program "Agricultural development and regulation of agricultural products, raw materials and food markets in the Kursk Region for 2014-2020."

The indicated program subordinates the development of the agrarian sector of the region to the program-target planning, and stimulates reasonable nature use. Note that this program is inherently consistent with the federal program for the development of agriculture and presents its adaptation for a specific region; however, it does not reflect the features and priorities of a particular region. The basic needs of socio-economic development are not performed in it, as the tasks of rational nature management are reflected and worked out not specifically for this territory.

The Kursk Region is an agrarian one cause of fertile lands, favorable natural and climatic conditions, and a sufficient amount of labor resources. Agriculture occupies $15 \%$ of its turnover of the region economy and brings about $20 \%$ of the region gross value. In recent years, the yield of grain crops is in the amount of $40-50 \mathrm{~kg} / \mathrm{ha}$; potatoes - 250 $\mathrm{kg} / \mathrm{ha}$, sugar beets - 400-600 kg/ha, corn for silage as the main feed crop - 300-350 $\mathrm{kg} / \mathrm{ha}$ [23].

After analyzing the existing set of tools of the state's influence on the development of the digital economy of rational environmental management in the agricultural sector of the region's economy, we note the institutional and infrastructural group, which reflects the need to develop research activity, to subsidize capital investments, to implement programs for improving the land fund quality, and to stimulate innovative activity of agricultural producers, expanding rural development based on innovative approach (rapid analysis of chemical composition of the soil, precision agriculture, etc.); to develop rural infrastructure in municipalities [23].

It is important to point out the emerging risk of lagging in the implementation of advanced technologies and the use of the fundamentals of the digital economy by small 
forms of farming in the countryside, which will lead to some reduction in production efficiency, financial stability and, as a consequence, decrease them numerically [24]. This trend will aggravate the problem of uniform spatial occupation of territories by the active, financially independent, working population of the country [25].

The role of the state is great, as being a "locomotive" it is obliged to form, support, popularize the production and consumption of environmentally friendly products based on the significant contribution of scientific schools and modern technological achievements in solving environmental safety problems and rational nature management.

One example of the informational introduction of modern management methods by the state, which have a synergistic effect for the real sector of the country's economy and the state administration, is the Federal State Information System "Mercury" implemented in the Russian Federation. It allows creating a single information platform for public authorities, producers and sellers of agricultural controlled products; automating the system of electronic certification of goods subject to state veterinary control throughout of the territory of the Russian Federation.

The presented system is a vivid example of the digitalization's introduction in economic processes, which ensures the ultimate buyer to get only safe high-quality products that contribute to optimal environmental management at the regional level. The practice, when 1 ton of milk comes from a dairy farm to a processing plant, and 1 ton of "natural" butter is produced from it, should completely be gone.

The above example will soon allow applying the term "transparent agricultural production" to the agricultural sector, which implies that the introduction of new technologies will significantly clarify the situation with the state of land, land use; monitor and confirm the process of production of organic food.

Thus, it can be confirmed that the state has a direct impact and acts as a "catalyst" for the introduction of the digital economy, in particular environmental management in the agricultural sector of the region's economy.

\section{Conclusion}

The widespread adoption of digital economy methods and techniques in the agricultural sector of the region's economy should ensure a more rational optimal nature management.

There are three main paradigms of environmental economics existing today, they find their adherents among the general mass of economists; however, thanks to modern innovative methods applied directly in production, as well as to improve the management process, the second paradigm is highlighted. The idea of which is based on the optimal use of natural resources. Moreover, the use of innovations in the environmental management process should ultimately contribute to improving the life quality of the region's population.

In conclusion, we highlight the key recommendations that should be paid attention to when implementing the elements of the digital economy on environmental management processes in the agricultural sector of the region's economy. 
The use of modern methods of the digital economy helps to minimize global environmental management problems: demographic, energy, water, food, depletion of land, forest resources.

It is advisable to supplement the national program "Digital Economy of the Russian Federation" with some sectors of the economy, in particular, pay more attention to the agricultural sector of the economy, for instance, add "Agriculture" to the programm as one of the strategic sectors for Russia, which has a very high potential for digitalization.

When developing governmental programs for the development, regulation and support of agriculture, it is important support innovative activity of agricultural producers, introduction of digital economy elements in the agricultural sector of the region's economy.

At the state level, it is essential to stimulate the production and consumption of environmentally friendly products based on the significant contribution of scientific schools, modern technological achievements in solving environmental safety problems, and rational nature management.

Thanks to modern digital technologies, the term "transparent agricultural production" is currently used, it implies the introduction of new technologies to clarify significantly the situation with the state of the land, as well as exercise control and confirm the process of production of organic food.

The introduction of the digital economy in the agricultural sector is the key to the formation of a modern, technological, sustainable and efficient agro-industrial complex, maintaining the saturation of rural areas with an active population (rural development) and ensuring rational nature management.

The development of a modern "smart" agricultural sector is impossible without a harmonious partnership between the state and business. The impact of the digital economy on environmental management processes in the agricultural sector of the region's economy cannot be underestimated. The solution to the problems raised in the article allows hopping for a significant economic effect and reduction of negative factors on the environmental management process; however, there are still many questions and unresolved problems concerning introduction of digital (automation) control of agricultural business processes.

\section{References}

(1) Voronina, A. A.; Preobrazhenskiy, B. G.; Sirotkina, N. V. The Best Available Technologies as Tools to Reduce a Negative Impact on the Environment: Rules and Selection Criteria (in Russian). Region: Systems, Economics, Management 2019, 1 (44), 193-197.

(2) Mazur, K. Economic Instruments of Influence Are on the Balanced Development of Agroecosistem (in Russian). International Scientific Journal of International Science. Series: Economic science 6, 9-14.

(3) Balatsky, E. V. Global Challenges of the Fourth Industrial Revolution (in Russian). Terra Economicus 2019, 17 (2), 6-22. 
(4) Kramin, T. V.; Klimanova, A. R. The Development of Digital Infrastructure in the Regions of Russia (in Russian). Terra Economicus 2019, 17 (2), 60-67.

(5) Koryagin, N. D.; Sukhorukov, A. I.; Chagaeva, B. B. The Impact of the Digital Economy on the Processes of Environmental Management in the Fuel and Energy Complex of Russia" (in Russian). In Current Problems of Project Management in the Investment and Construction Sphere and Nature Management, Materials of the VIII International Scientific and Practical Conference of the Department of Project and Program Management; Plekhanov Russian University of Economics: Moscow, 2018; pp 290-293.

(6) Chesbrough, W. H. Open Innovation: The New Imperative for Creating and Profiting from Technology; Harvard Business School Publishing: Cambridge, MA, 2003.

(7) Anisimov, Yu. P.; Usacheva, I. V. Economic Growth of Production Based on Innovation (in Russian); Institute of Management, Marketing and Finance: Voronezh, 2008.

(8) Trott, P. Innovation Management and New Product Development, 5th ed.; Pearson Education Limited: London, 2012.

(9) Blackwell, K.; Fazzina, D. Open innovation: facts, fiction, and future https://www.nerac.com/open-innovation-facts-fiction-and-future/ (accessed Feb 22, 2020).

(10) Glassman, B.; Walton, A. OPEN Innovation's Common Issues and Potential Roadblocks. Innovation White Paper Series 2010, Special Issue, 1-7.

(11) Titova, M. V.; Goncharov, A. Y.; Sirotkina, N. V. Regional Innovation Subsystem: Assessment and Planning of Development Parameters (in Russian). Modern Economics: Problems and Solutions 2016, 12, 172-185. https://doi.org/10.17308/meps.2015.12/1367.

(12) Bezrukova, T. L.; Lesnykh, R. A.; Sirotkina, N. V.; Solomakhin, A. N. Management of the Regional Economy Based on the Formation of Investment Projects (in Russian); Voronezh State Forestry University named after G.F. Morozov: Voronezh, 2006.

(13) Goncharov, A. Yu.; Polyakov, A. V.; Sirotkina, N. V. Trends and Prospects of Interaction of Agents of the Innovative Environment of the Region in the Context of a Cognitive Economy (in Russian). Delta Science 2015, 1 (1), 4-17.

(14) Anisimov, Yu. P.; Sirotkina, N. V. Indicative Management of the Innovative Environment of Modern Business; Scientific Book: Voronezh, 2008.

(15) Sirotkina, N. V.; Lanskykh, E. A. Clustering as a Promising Direction for Increasing the Competitiveness of the Regional Economy (in Russian). Russian Transport 2011, 2, 182-184.

(16) Andreevna-Gubanova, M.; Anatolyevna-Bessonova, E.; Fedorovna-Anoshina, I. Investment Climate as a Factor of Social and Economic Development in Regions of the Russian Federation (in Russian). Istrazivanja i Projektovanja za Privredu 2017, 15 (4), 455-458. https://doi.org/10.5937/jaes15-15454.

(17) Problems of Formation of Perspective Growth Points of High-Tech Productions. Advances in Intelligent Systems and Computing 2018, 622, 469-475,. 
(18) Serebryakova, M. Uncertainty in Agriculture: A Regional Aspect. International Agricultural Journal 2017, 3, 23-27.

(19) Amirova, E. F.; Voronkova, O. Y.; Pyurveeva, K. A.; Shatalov, M. A.; Panteleeva, T. A.; Sorokina, O. A. Functioning of Agroindustrial Complex in the Conditions of Digital Economy». International Journal of Mechanical Engineering and Technology 2018, 9 (12), 586-594,.

(20) Vorotnikov, I. L.; Neyfeld, V. V. The Efficacy of Digital Technology in Land Administration of Municipalities of the Saratov Region (in Russian). The Agrarian Scientific Journal 2018, 6, 76-81. https://doi.org/10.28983/asj.v0i6.510.

(21) TAdviser. National program Digital Economy of the Russian Federation (in Russian) http://www.tadviser.ru/index.php/Статья:Национальная_программа_Цифровая_э кономика_Российской_Федерации (accessed Feb 23, 2020).

TAdviser. Digital Economy of Russia http://www.tadviser.ru/index.php/Статья:Цифровая_экономика_России (accessed Feb 23, 2020).

(23) Zhakhov, N. V. State Regulation of the Systemic Development of the Agricultural Sector of the Region's Economy (in Russian). Doctoral thesis, Southwestern State University, Kursk, Russia, 2018.

(24) Zhakhov, N. V.; Krivoshlykov, V. S. A Critical Analysis of Planned Measures for the Development of Agricultural Production at the Regional Level" (in Russian). In Actual issues of managing local environmental and economic systems based on improving the competence mechanisms of socio-economic development of territories collection of materials of the All-Russian Scientific and Practical Conference; Kursk State University: Kursk, 2017; pp 29-34.

(25) Zhahov, N. V.; Krivoshlykov, V. S.; Shatokhin, M. V. Ways of Modern Agriculture in: Specifics and State Support". In Proceedings of the 30th International Business Information Management Association Conference, IBIMA 2017 - Vision 2020: Sustainable Economic development, Innovation Management, and Global Growth 30, Vision 2020: Sustainable Economic development, Innovation Management, and Global Growth; Soliman, K. S., Ed.; IBIMA: Madrid, 2017; pp 3646-3652.

\section{Information about Authors}

Nikolay Vladimirovich ZHAKHOV: D.Sc. in Economics, Associate Professor, Department of Economics, Management and Audit, South-West State University; 19/1 Chelyuskintsev Str., Kursk, 305004, Russia; e-mail: zhakhov@mail.ru.

Vladimir Sergeevich KRIVOSHLYKOV: Ph.D. in Economics, Associate Professor, Department of Management, Marketing and Personnel Management, Kursk State University; 29 Radishchev Str., Kursk, 305000, Russia.

Natalya Aleksandrovna SLAVOVA: Ph.D. in Law, Associate Professor, Department of Legal Disciplines, Branch of the Russian State University for the Humanities in Domodedovo; 4 bldg. 2 Kashirskoye Highway, Domodedovo, Moscow Region, 142000, Russia. 
Irina Alekseevna GLEBOVA: Ph.D. in Agriculture, Associate Professor, Head of the Department of Ecology and Nature Management, Moscow State University of Technology and Management named after K.G. Razumovsky; 73 Zemlyanoy Val Str., Moscow, 109004, Russia.

Vladislav Vladimirovich TURCHAKOV: Senior Lecturer, Department of Ecology and Nature Management, Moscow State University of Technology and Management named after K.G. Razumovsky; 73 Zemlyanoy Val Str., Moscow, 109004, Russia. 